\title{
Heterozygous knockout of the IRS-1 gene in mice enhances obesity-linked insulin resistance: a possible model for the development of type 2 diabetes
}

\author{
A Shirakami, T Toyonaga, K Tsuruzoe, T Shirotani, K Matsumoto, \\ K Yoshizato, J Kawashima, Y Hirashima, N Miyamura, C R Kahn ${ }^{1}$ \\ and E Araki \\ Department of Metabolic Medicine, Kumamoto University School of Medicine, 1-1-1 Honjo, Kumamoto 860-8556, Japan \\ ${ }^{1}$ Joslin Diabetes Center and Harvard Medical School, 1 Joslin Place, Boston, Massachusetts 02215, USA \\ (Requests for offprints should be addressed to E Araki; Email: earaki@kaiju.medic.kumamoto-u.ac.jp)
}

\begin{abstract}
Insulin receptor substrate 1 (IRS-1) gene polymorphisms have been identified in type 2 diabetic patients; however, it is unclear how such polymorphisms contribute to the development of diabetes. Here we introduced obesity in heterozygous IRS-1 knockout (IRS-1 ${ }^{+/-}$) mice by goldthioglucose (GTG) injection and studied the impact of reduced IRS-1 expression on obesity-linked insulin resistance. GTG injection resulted in $\sim 30 \%$ weight gain in IRS $-1^{+/-}$and wild type (WT) mice, compared with saline-injected controls. There was no difference in insulin sensitivity between lean IRS-1 ${ }^{+/-}$and lean WT. Elevated fasting insulin levels but no change in fasting glucose were noted in obese IRS-1 $1^{+1-}$ and WT
\end{abstract}

compared with the respective lean controls. Importantly, fasting insulin in obese IRS-1 $1^{+/-}$was $1 \cdot 5$-fold higher $(P<0 \cdot 05)$ than in obese WT, and an insulin tolerance test showed a profound insulin resistance in obese IRS $-1^{+/-}$ compared with obese WT. The islets of obese IRS-1 ${ }^{+/-}$ were 1.4-fold larger than those of obese WT. The expression of insulin receptor and IRS-1 and IRS-2 was decreased in obese IRS $-1^{+/-}$, which could in part explain the profound insulin resistance in these mice. Our results suggest that IRS-1 is the suspected gene for type 2 diabetes and its polymorphisms could worsen insulin resistance in the presence of other additional factors, such as obesity.

Journal of Endocrinology (2002) 174, 309-319

\section{Introduction}

Type 2 diabetes mellitus is characterized by insulin resistance in peripheral tissues and failure of insulin secretion from pancreatic $\beta$-cells (O'Rahilly et al. 1995). Part of these abnormalities seem to be genetically defined. Several candidate genes for insulin resistance have been proposed, which include the genes encoding the molecules of the insulin signaling pathway (O'Rahilly et al. 1995), glycolysis (Ristow et al. 1999) and glyconeogenesis (Ludwig et al. 1996). In addition, some of the genes involved in obesity, including peroxidase proliferating activator receptor- $\gamma$ (Ristow et al. 1998) and uncoupling protein-1 (Heilbronn et al. 2000), may also contribute to insulin sensitivity.

Insulin receptor substrate-1 (IRS-1) is one of the major substrates of insulin receptor tyrosine kinase (Araki et al. 1993). After insulin stimulation, IRS-1 is immediately tyrosine phosphorylated by activated receptor tyrosine kinase, and some phosphorylated tyrosine residues of IRS-1 serve as docking sites for several src homology 2
(SH2)-containing proteins, including phosphatidylinositol 3-kinase (PI 3-kinase), SH2-containing protein tyrosine phosphatase-2 and growth factor-bound protein-2 (Myers et al. 1994, Argetsinger et al. 1995). Binding of these SH2 proteins to IRS-1 results in the activation of two major signaling pathways, the mitogen activated protein kinase pathway and the PI 3-kinase pathway, both of which mediate various biological effects of insulin.

The role of IRS-1 in insulin signaling in vivo has been confirmed by generating IRS-1 knockout mice by targeted disruption of the IRS-1 gene (Araki et al. 1994, Tamemoto et al. 1994). The IRS-1 homozygous knockout (IRS-1 ${ }^{-{ }^{-}}$) mice show impaired intrauterine growth, resistance to insulin and insulin-like growth factor-I (IGFI), and glucose intolerance upon i.p. glucose loading. On the other hand, in spite of the low expression of IRS-1 protein, IRS-1 heterozygous knockout (IRS- $1^{+/-}$) mice show no significant abnormalities in insulin sensitivity and glucose homeostasis.

Previous studies from our laboratories and those of other investigators described several polymorphisms of the 
IRS-1 gene in patients with type 2 diabetes (Almind et al. 1993, Ura et al. 1996). Glycine to arginine substitution at codon 971 of IRS-1 gene (G971R) is the most frequent polymorphism in any population examined. The prevalence of G971R polymorphism is significantly higher in patients with type 2 diabetes than in normal subjects, and subjects who carry IRS-1 polymorphism tend to be insulin-resistant compared with those with no such mutation (Ura et al. 1996). Functional analysis of mutant IRS-1 confirmed that G971R mutant showed impaired insulin-induced PI 3-kinase activation and mitogenesis in the hematopoietic 32 D cell line (Almind et al. 1996, Yoshimura et al. 1997). These in vitro data strongly suggest that IRS-1 abnormalities could contribute to the development of insulin resistance in human. However, it is still not clear whether or how IRS-1 abnormalities could lead to insulin resistance in humans since most IRS-1 polymorphisms exist in a heterozygous manner in type 2 diabetes, whereas the heterozygous IRS-1 knockout mice show neither impairment of glucose homeostasis nor insulin sensitivity.

It is well known that environmental factors such as obesity and high fat diet are associated with increased prevalence of type 2 diabetes. In fact, the number of type 2 diabetes patients in Asian countries including Japan has markedly increased during the last few decades due to changes in life style (King \& Rewers 1993). Furthermore, Clausen et al. (1995) reported that obese subjects who carry IRS-1 gene polymorphism are more resistant to insulin than those who have no mutation in the IRS-1 gene, whereas non-obese carriers of the IRS-1 gene polymorphism have normal insulin sensitivity. These findings suggest that the impact of IRS-1 gene polymorphism becomes overt in the presence of obesity. In order to examine the interaction between obesity and IRS- 1 gene polymorphism, we induced obesity in IRS $-1^{+/-}$mice by injection of gold-thioglucose (GTG). Using this model, we studied the impact of reduced IRS-1 expression on obesity-linked insulin resistance in vivo, and investigated the mechanisms that underlie insulin resistance in obese IRS $-1^{+/-}$mice.

\section{Materials and Methods}

\section{Establishment of obese IRS-1 ${ }^{+/-}$mice}

Animal care and experiments were carried out in accordance with institutional animal care regulations. IRS-1 heterozygous knockout mice (IRS-1 ${ }^{+/-}$) were generated by mating female IRS- $1^{+/}$mice with male IRS- $1^{+/-}$ mice (Araki et al. 1994). The genotypes of mice were examined by PCR analysis after extraction of genomic DNA from the tail. Only male mice were used in this study. Obesity was introduced by a single i.p. injection of $0.5 \mathrm{mg} / \mathrm{g}$ body weight of GTG (Sigma Chemical, St Louis, MO, USA) at 6 weeks of age. Mice were kept on a $12 \mathrm{~h}$ light: $12 \mathrm{~h}$ darkness cycle, with the light cycle between 0700 and $1900 \mathrm{~h}$. The mice were allowed free access to food and water.

Assessment of plasma parameters, i.p. glucose tolerance test and i.p. insulin tolerance test

Blood samples were obtained from snipped tail ends for determination of insulin and glucose levels. Blood glucose concentration was measured by the enzymatic assay (Arkray, Kyoto, Japan). Insulin concentration was measured by ELISA (Morinaga, Yokohama, Japan). An i.p. glucose tolerance test was performed after overnight fasting by administering $2 \cdot 0 \mathrm{~g}$ glucose $/ \mathrm{kg}$ body weight via the peritoneal cavity in conscious mice at 40 weeks of age. The area under the curve (AUC) was calculated as the integrated blood glucose level during the tolerance test. An i.p. insulin tolerance test was performed at 35 and 45 weeks of age by administering $1.0 \mathrm{U}$ insulin $/ \mathrm{kg}$ body weight. For a more precise assessment of insulin sensitivity, we calculated the area over the curve (AOC), which represented the integrated reduced level of blood glucose during the insulin tolerance test.

\section{Morphological analysis of the pancreas}

The pancreas was obtained from mice at 50 weeks of age, fixed in paraffin, and cut into 10 sections ( $5 \mu \mathrm{m}$ thick) separated by $200 \mu \mathrm{m}$. Sections were immunostained with anti-insulin, anti-glucagon or anti-somatostatin antibodies (Nichirei, Tokyo, Japan). Biotinylated goat anti-rabbit IgG coupled to peroxidase and alkaline phosphatase, and streptavidin-biotin complex were used as secondary antibodies. 3'3'-Diaminobenzidine or Fast Red Substrate Kit (Nichirei) was used as substrate respectively. Sections were then counterstained with hematoxylin-eosin (HE) and visualized using an IX50 microscope (Olympus, Tokyo, Japan). At least 20 islets in each section were randomly selected and analyzed. The area of each islet was measured quantitatively with an image analysis software (NIH, Bethesda, MD, USA).

\section{Immunoprecipitation and Western blotting}

Mice were anesthetized with $100 \mathrm{mg} / \mathrm{kg}$ sodium pentobarbital injected i.p. Following the loss of pedal and corneal reflexes, saline or $5.0 \mathrm{U}$ regular insulin were injected into the portal vein. The liver, gastrocnemius, and quadriceps muscles were dissected out 1 and $3 \mathrm{~min}$ after insulin injection, and immediately frozen in liquid nitrogen. The frozen tissue was homogenized in ice-cold lysis buffer $(1 \%$ Triton X-100, $50 \mathrm{mM}$ Hepes, $\mathrm{pH} 7 \cdot 4$, $100 \mathrm{mM}$ sodium pyrophosphate, $100 \mathrm{mM}$ sodium fluoride, $10 \mathrm{mM}$ EDTA, $5 \mathrm{mM}$ sodium vanadate, aprotinin $(10 \mu \mathrm{g} / \mathrm{ml})$, leupeptin $(5 \mu \mathrm{g} / \mathrm{ml})$ and polymethylsulfonyl fluoride $(34 \mu \mathrm{g} / \mathrm{ml}))$ using a Polytron PTA $20 \mathrm{~S}$ generator 
operated at maximum speed for $30 \mathrm{~s}$. The insoluble material was removed by centrifugation at $125000 \mathrm{~g}$. in a 70 Ti rotor (Beckman Instruments, Inc., Fullerton, CA, USA) for $60 \mathrm{~min}$, and equal amounts of the supernatant were subjected to immunoprecipitation for $120 \mathrm{~min}$ using the indicated antibodies. Subsequently, protein A-Sepharose was added and followed by incubation for another $60 \mathrm{~min}$. The samples were processed for SDSPAGE and Western blotting as described previously (Folli et al. 1993).

\section{PI 3-kinase assay}

Immune-complexed PI 3-kinase activity was measured by in vitro phosphorylation of phosphatidylinositides (PI) as described previously (Folli et al. 1993). Immune complexes were incubated in $45 \mu \mathrm{l}$ reaction buffer containing $10 \mu \mathrm{M}$ ATP, $30 \mu \mathrm{Ci}\left[\gamma_{-}{ }^{32} \mathrm{P}\right] \mathrm{ATP}$ and $10 \mu \mathrm{g}$ PI at room temperature under constant shaking. After $10 \mathrm{~min}$, the reaction was stopped by the addition of $250 \mu \mathrm{l} 1 \mathrm{M} \mathrm{HCl}$ and $80 \mu \mathrm{l} \mathrm{CHCl}_{3} /$ methanol (2:1). The samples were centrifuged, and the lower organic phase was removed and applied to a silica gel TLC plate (Merck, Darmstadt, Germany) coated with $1 \%$ potassium oxalate. TLC plates were developed in $\mathrm{CHCl}_{3} / \mathrm{CH}_{3} \mathrm{OH} / \mathrm{H}_{2} \mathrm{O} / \mathrm{NH}_{4} \mathrm{OH}$ (60:47:11·3:2), dried, and visualized by autoradiography. The ${ }^{32}$ P-labeled PI was quantified using NIH image analysis software.

\section{Statistical analysis}

All data are expressed as means \pm S.D. Differences between groups were examined for statistical significance using the non-parametric Mann-Whitney U-test. A $P$ value less than 0.05 denoted the presence of a statistically significant difference.

\section{Results}

\section{Development of obesity following GTG administration}

Body weight of both IRS-1 ${ }^{+/-}$and wild type (WT) mice increased by approximately $30 \%$ at 9 weeks after GTG administration, compared with the relative saline-injected control groups (IRS $-1^{+/-}$group: $40 \cdot 2 \pm 2 \cdot 6 \mathrm{~g}$ vs control: $33 \cdot 0 \pm 4 \cdot 0 \mathrm{~g}, P<0 \cdot 001$, and WT group: $40 \cdot 2 \pm 3 \cdot 4 \mathrm{~g}$, vs control: $31 \cdot 0 \pm 4 \cdot 7 \mathrm{~g}, P<0 \cdot 001$ ) (Fig. 1). There were no significant differences in body weight between obese WT and obese IRS $-1^{+/}$mice, and between lean WT and lean IRS $-1^{+/-}$mice. The increase in body weight $(\sim 30 \%)$ of the GTG-injected groups was maintained until 45 weeks of age.

\section{Fasting blood glucose and fasting serum insulin concentrations in WT and IRS-1 $1^{+/-}$mice}

Fasting blood glucose and serum insulin concentrations were measured at 15 weeks of age and every 15 weeks

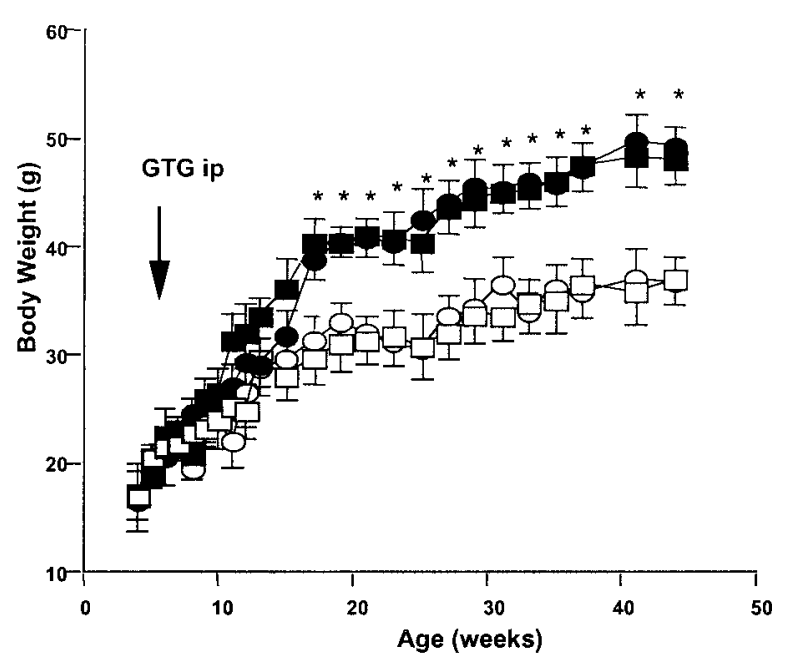

Figure 1 Growth curves for WT and insulin receptor substrate 1 $(\text { IRS-1 })^{+/-}$mice following administration of gold-thioglucose (GTG). GTG or saline was injected into the peritoneal cavity of mice at 6 weeks of age. Body weight of GTG-injected WT (ם) and IRS $-1^{+} /^{-}(\mathbf{O})$ mice, and saline-injected WT $(\square)$ and IRS-1 ${ }^{+/-}$ (O) mice was measured until 45 weeks of age. Data are means \pm S.D. of ten mice in each group. ${ }^{*} P<0 \cdot 001$ vs lean mice group.

thereafter. There was no significant difference in fasting blood glucose levels among four groups at 15 weeks of age (Fig. 2A). Blood glucose levels did not change significantly until 45 weeks of age in all groups (data not shown). There was no significant change in fasting serum insulin concentrations between lean WT and lean IRS-1 $1^{+\prime-}$ mice at 15 weeks (Fig. 2B). In contrast, the mean fasting serum insulin concentrations in obese WT mice were about three times higher than those of lean WT controls $(1 \cdot 62 \pm 0 \cdot 42$ vs $0.56 \pm 0.30 \mathrm{ng} / \mathrm{ml}, P<0 \cdot 01)$. The mean insulin concentration of obese IRS-1 $1^{+/-}$mice $(2.56 \pm 0.78 \mathrm{ng} / \mathrm{ml})$ was also significantly higher than that of lean IRS- $1^{+1-}$ mice $(0 \cdot 65 \pm 0.57 \mathrm{ng} / \mathrm{ml}, P<0 \cdot 01)$. Importantly, fasting insulin concentrations in obese IRS- $1^{+-}$mice were significantly higher $(P<0 \cdot 05)$ than in obese WT mice.

\section{Insulin tolerance and glucose tolerance tests}

To assess glucose intolerance in IRS $-1^{+/-}$mice, glucose $(2.0 \mathrm{~g} / \mathrm{kg}$ body weight $)$ was injected i.p. at 40 weeks of age. Obese IRS $-1^{+\prime}-$ and obese WT mice showed a significant elevation in blood glucose concentrations after glucose loading compared with the respective lean controls $(P<0 \cdot 01)$ (Fig. 3). Furthermore, blood glucose levels in obese IRS-1 ${ }^{+\zeta-}$ mice at $60 \mathrm{~min}$ after glucose challenge were higher than in obese WT mice. However, the AUC of obese WT mice (47 $408 \pm 3492$ ) was not significantly different from that of obese IRS $-1^{+/-}$mice (45 $982 \pm 2579)$. 
A

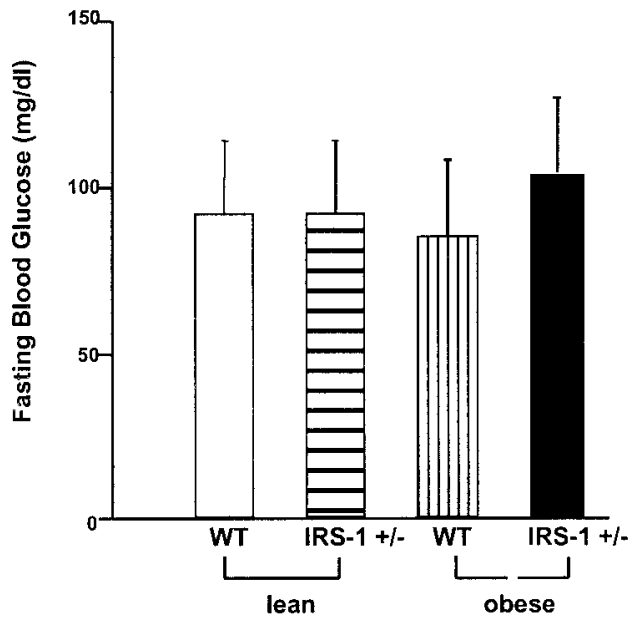

B

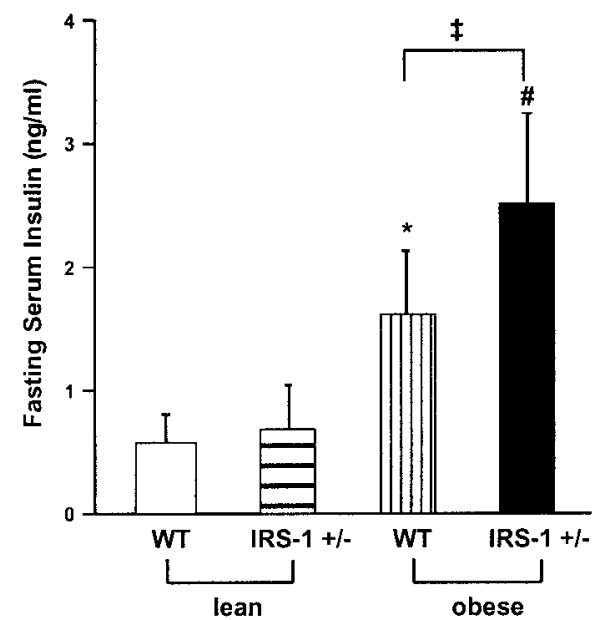

Figure 2 Fasting blood glucose concentrations (A) and serum insulin concentrations (B) of mice at 15 weeks of age. After overnight fasting, blood samples were collected from the tail and blood glucose and serum insulin concentrations were determined as described in Materials and Methods. Data are means \pm S.D. of ten mice in each group. ${ }^{*} P<0.01$ vs lean WT, ${ }^{\#} P<0 \cdot 01$ vs lean IRS- $1^{+/-},{ }^{\ddagger} P<0 \cdot 05$.

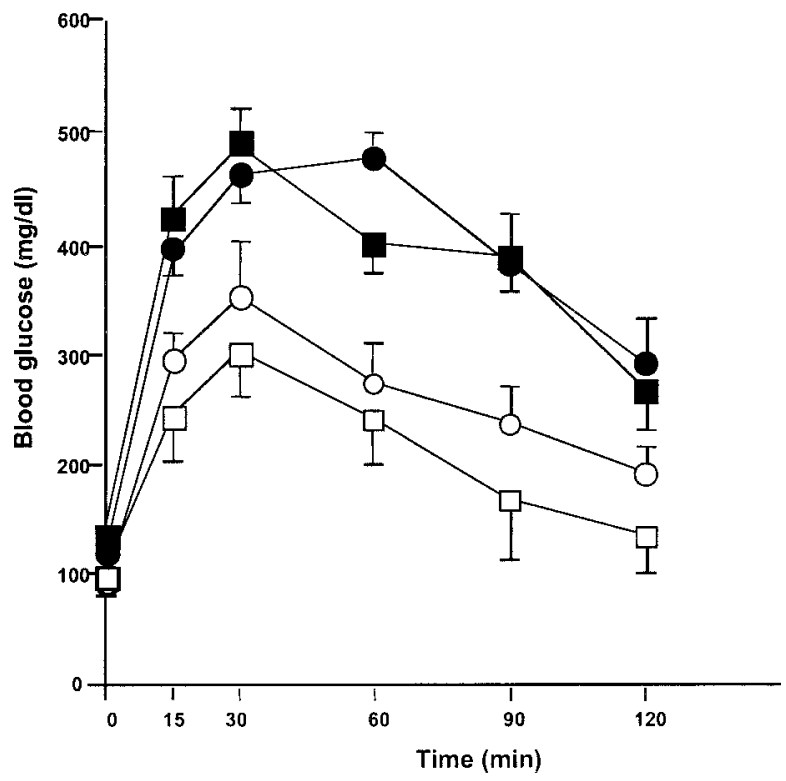

Figure 3 I.p. glucose tolerance test in lean WT $(\square)$, lean IRS- $1^{+/-}$ $(\bigcirc)$, obese WT $(\boldsymbol{\square})$, and obese IRS- $1^{+/-}(\mathbf{O})$ mice. After overnight fasting, glucose $(2 \cdot 0 \mathrm{~g} / \mathrm{kg}$ body weight) was injected into the peritoneal cavity of 40-week-old mice. Blood samples were collected from the tail at the indicated time points and glucose concentrations were measured. Data are means \pm S.D. of five mice in each group.

We also assessed insulin sensitivity at 35 and 45 weeks of age by an i.p. insulin tolerance test. At 35 weeks of age, both obese groups showed a significant reduction in glucose-lowering effect of insulin compared with their lean controls (data not shown). Glucose levels after insulin challenge tended to be higher in obese IRS-1 ${ }^{+/-}$mice

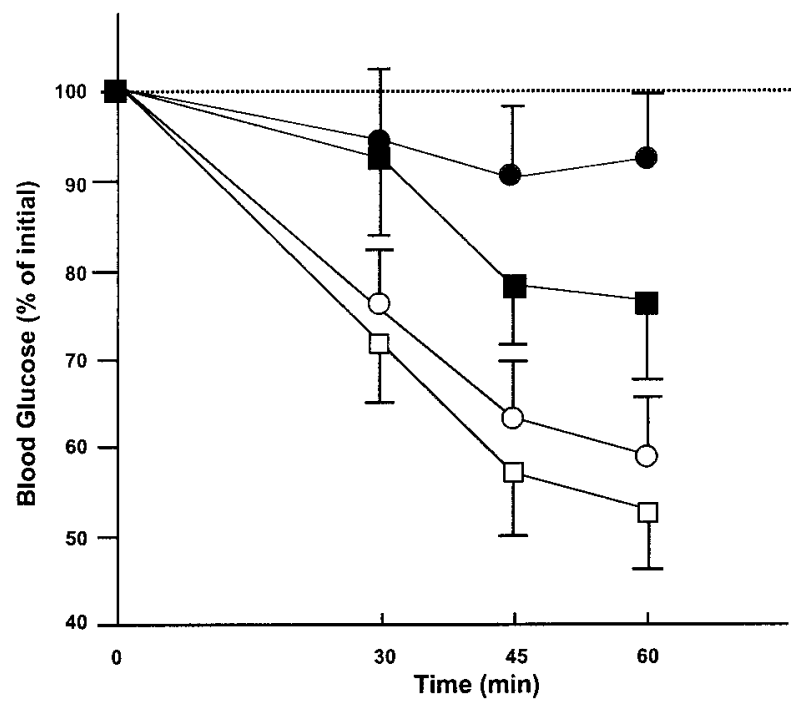

Figure 4 Insulin tolerance test in lean WT $(\square)$, lean IRS- $1^{+/-}(\bigcirc)$, obese WT $(\mathbf{\square})$, and obese IRS-1 $1^{+/-}(\mathbf{)})$ mice. After overnight fasting, insulin $(1 \cdot 0 \mathrm{U} / \mathrm{kg}$ body weight) was injected into the peritoneal cavity of 45-week-old mice. Blood samples were collected from the tail at the indicated time and glucose concentrations were measured. Data are means \pm S.D. of five mice in each group.

than in obese WT mice, albeit statistically insignificant (data not shown). An i.p. insulin tolerance test at 45 weeks of age showed that both obese WT and obese IRS-1 ${ }^{+/-}$ mice exhibited a significant reduction in the glucoselowering effect of insulin compared with their lean controls at all times after insulin challenge (Fig. 4). Importantly, the glucose-lowering effect of insulin in obese IRS $-1^{+/-}$mice was markedly diminished 
compared with obese WT mice. For a more precise assessment of the insulin-lowering effect, we calculated the AOC. The AOC of lean WT mice $(1692 \pm 201)$ was not significantly different from that of lean IRS-1 $1^{+/-}$ mice $(1476 \pm 201)$. However, the AOC of obese IRS $-1^{+/-}$ mice $(315 \pm 319)$ was significantly lower than that of obese WT mice $(692 \pm 333)$.

\section{Morphological analysis of the pancreas}

Islets in the pancreas section of obese WT and obese IRS $-1^{+/-}$mice were significantly larger than those in their lean mice controls (Figs 5 and 6A). Interestingly, the mean islet size of obese IRS $-1^{+1-}$ mice was $36 \%$ larger than that of obese WT mice $(P<0 \cdot 05)$, whereas there was no difference in islet size between lean WT and lean IRS-1 $1^{+/-}$mice (Figs 5 and 6A). Next we analyzed sections immunostained for insulin, glucagon and somatostatin. There was no obvious degranulation of $\beta$-cells in anti-insulin antibody stained sections from all groups. Furthermore, the relative number of $\beta$-cells in the islets was higher in obese IRS-1 ${ }^{+/-}$mice than in obese WT mice (Figs 5 and $6 \mathrm{~B}$ ). In contrast, there was no significant difference in the number of non- $\beta$-cells between the two obese groups (Figs 5 and 6C).

\section{Expression of insulin receptor and IRS-1 and IRS-2 in liver and skeletal muscles}

To elucidate the molecular mechanisms of enhanced insulin resistance in obese IRS $-1^{+/-}$mice, we examined the expression levels of insulin receptor and IRS-1 and IRS-2 proteins in the liver and muscles. Quantitative analysis showed no differences in the expression of insulin receptor between lean WT and lean IRS-1 ${ }^{+/-}$mice, in both the liver and muscles (Fig. 7A and B). Furthermore, the expression of the insulin receptor in the liver and muscles of both obese groups was significantly lower than in their lean controls (by 55\% in WT and by $83 \%$ in IRS $-1^{+/}$in the liver, $44 \%$ in WT and $62 \%$ in IRS $-1^{+/-}$ in muscles). There was also no difference in insulin receptor expression in the muscles between obese WT and obese IRS $-1^{+/-}$mice (Fig. 7B). Interestingly, insulin receptor expression in the liver of obese IRS-1 ${ }^{+/}-$mice was 39\% of that of obese WT mice (Fig. 7A).

As expected, IRS-1 protein content in lean IRS-1 ${ }^{+/-}$ was approximately half of that in lean WT mice in the liver and muscles (59 and 44\% respectively) (Fig. 7C and D). Compared with their lean controls, IRS-1 protein content was significantly reduced by $83 \%$ in obese WT and by $74 \%$ in obese IRS-1 ${ }^{+/-}$in the liver (Fig. 7C), and reduced by $28 \%$ in obese WT and by $32 \%$ in obese IRS $-1^{+/-}$in muscles (Fig. 7D). Importantly, IRS-1 content in the muscles of obese IRS- $1^{+/}$was $45 \%$ of that in obese WT mice, but there was no difference in IRS-1 levels in the liver between the two obese groups.
Interestingly, the expression of IRS-2 protein in lean IRS $-1^{+/}-$mice was significantly increased in both the liver and muscles compared with lean WT mice (Fig. 7E and F). IRS-2 expression in the liver was significantly reduced in obese WT and in obese IRS $-1^{+/-}$mice, compared with their lean controls (by 58 and by $66 \%$ respectively) (Fig. 7E). Similarly, IRS-2 protein level in the muscles of obese groups tended to be lower in WT (by $23 \%$ ) and in IRS-1 $1^{+/-}$(by 52\%) than in their lean controls (Fig. 7F). There were no differences in IRS-2 levels in both the liver and muscles between obese IRS $-1^{+/-}$mice and obese WT mice.

\section{PI 3-kinase activity}

Activation of PI 3-kinase is crucial for the metabolic action of insulin (Hara et al. 1994). Therefore, we examined the expression of p85 subunit of PI 3-kinase and PI 3-kinase activity associated with the immunoprecipitant using antiphosphotyrosine antibody. In contrast to insulin receptor or IRS proteins, there was no change in expression level of p85 subunit of PI 3-kinase among the four groups (Fig. 8A and $\mathrm{B})$. There was also no difference in insulin-stimulated PI 3-kinase activity between lean WT and lean IRS-1 ${ }^{+/-}$ mice in both the liver (Fig. 8C) and muscles (Fig. 8D). The two obese groups showed a significant reduction in insulin-stimulated PI 3-kinase activity compared with their lean controls in the liver (diminished by 46 and by $60 \%$ in obese WT and obese IRS- $1^{+/-}$mice respectively) (Fig. 8C) and in muscles (by 27 and by 55\% in WT and IRS $-1^{+/}$respectively) (Fig. 8D). PI 3-kinase activity in the muscles of obese IRS- $1^{+\prime-}$ mice was significantly lower than that in obese WT (by 36\%). PI 3-kinase activity in the liver of obese IRS $-1^{+/-}$mice tended to be lower than that in obese WT, albeit statistically insignificant $(P=0 \cdot 07)$.

\section{Discussion}

In the present study, we induced hypothalamic obesity in IRS $-1^{+/-}$mice and examined the impact of decreased IRS-1 expression on the obesity-linked insulin resistance in vivo. After i.p. administration, GTG is mainly transported to cells of the ventromedial hypothalamus and causes necrotic lesions in that area. In rodents, the GTGinduced hypothalamic lesion causes insulin resistance and obesity, which is mainly due to the associated hyperphagia (Le Marchand et al. 1978). The first events after hypothalamic lesion is hyperphagia, and insulin resistance is considered to be a secondary event due to weight gain and hyperinsulinemia, although the exact cause of hyperinsulinemia in GTG-induced obesity is unclear at present (Tsao et al. 2000).

Administration of GTG in IRS-1 ${ }^{+/-}$mice resulted in increased food consumption and subsequent increase 
A lean WT
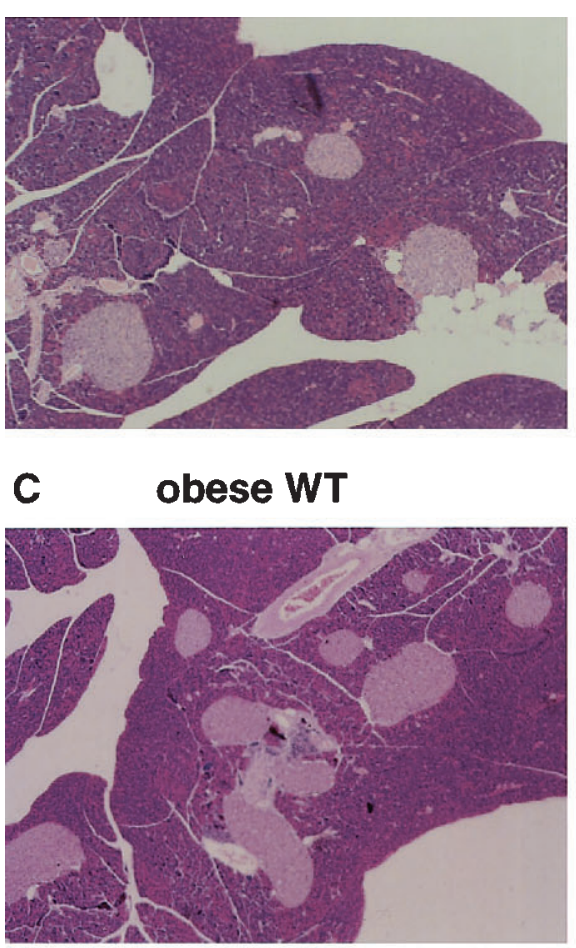

E obese WT

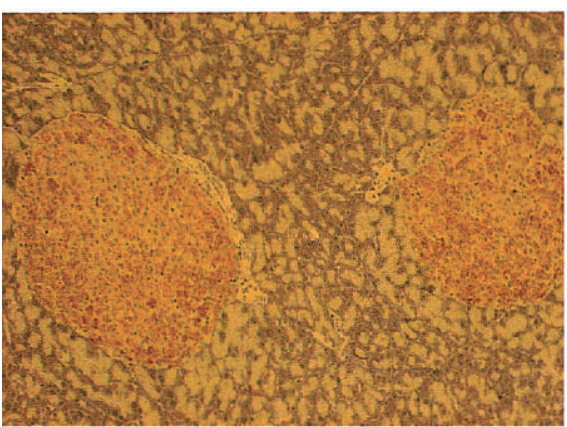

\section{G obese WT}

\section{$\alpha$-glucagon \\ $\&$ \\ $\alpha$-somatostatin}

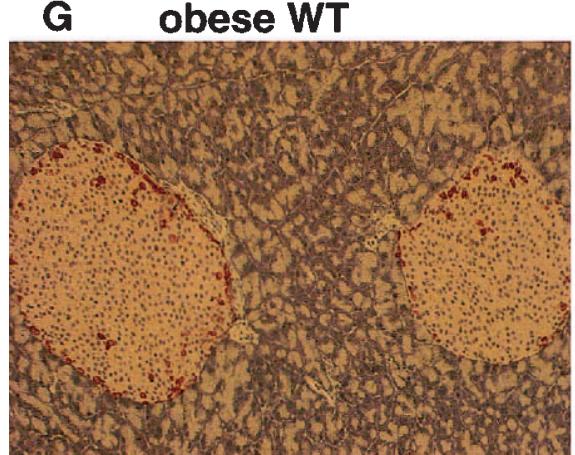

B lean IRS-1 +/-

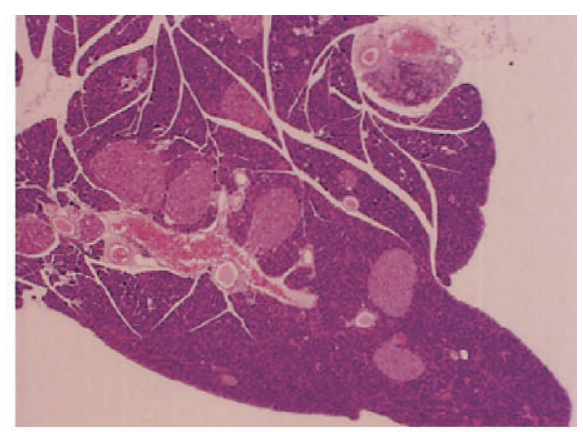

D obese IRS-1+/-

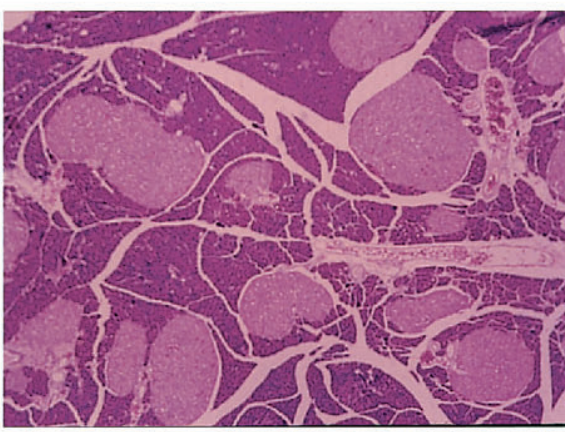

F obese IRS-1+/-

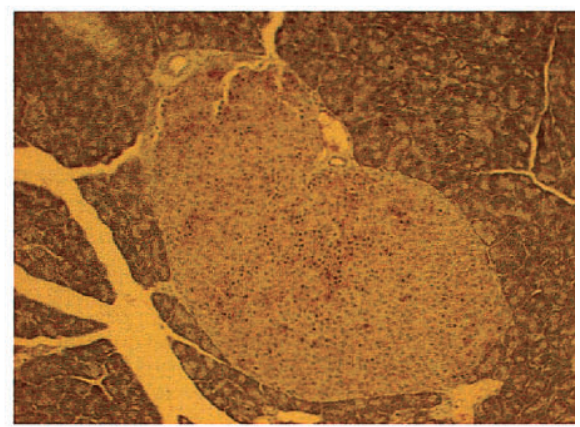

H obese IRS-1+/-

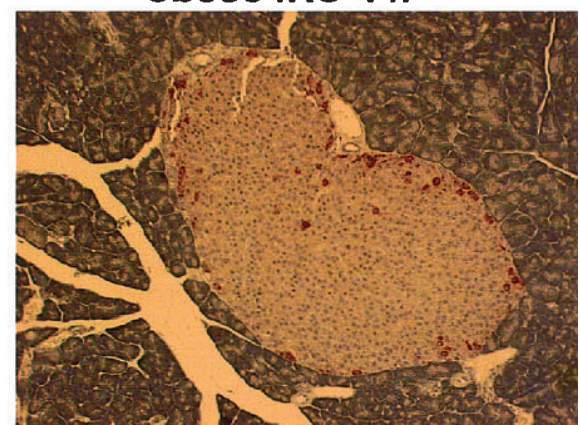



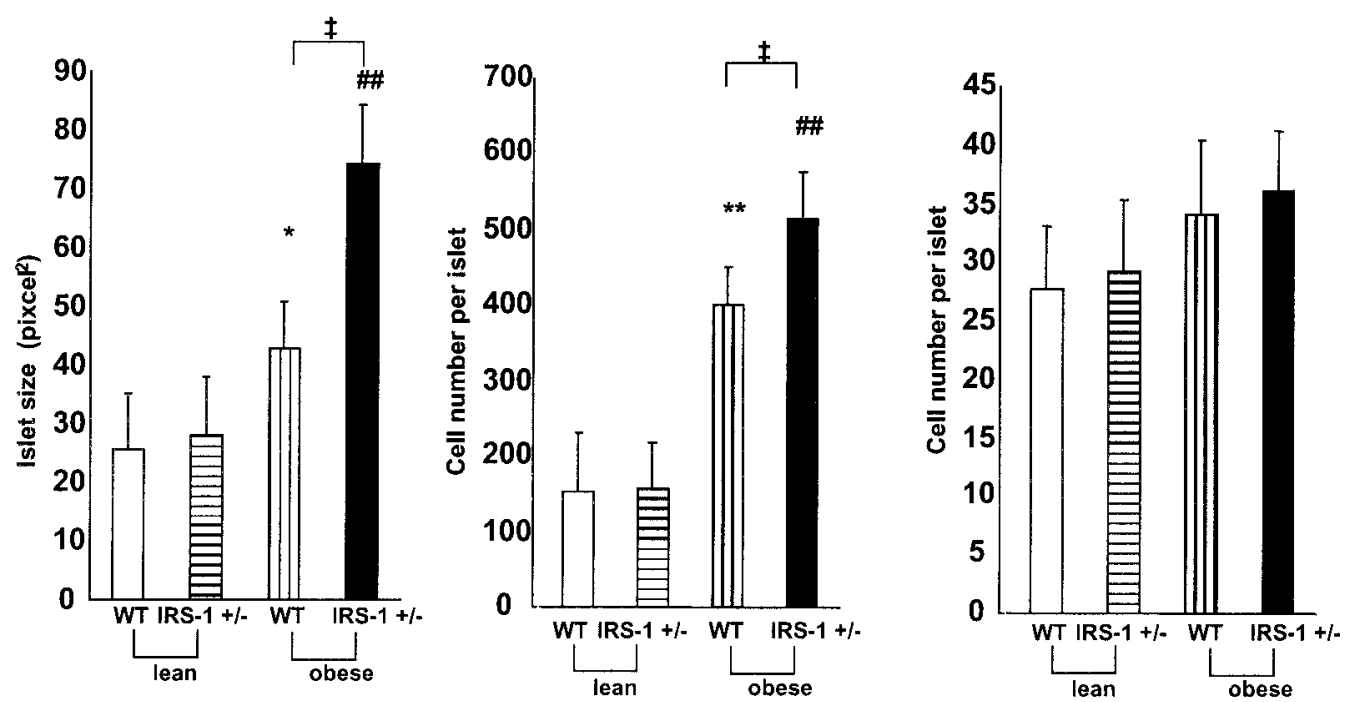

Figure 6 Islet size and number of $\beta$-cells and non- $\beta$-cells in the pancreatic islets. Islet size (A), and number of $\beta$-cells (B) and non- $\beta$-cells (C) per islet were quantified as described in Materials and Methods. Data are means \pm S.D. of five mice in each group. ${ }^{*} P<0 \cdot 05,{ }^{*}{ }^{*} P<0 \cdot 001$ vs lean WT, ${ }^{\# \#} P<0 \cdot 01$ vs lean IRS- $1^{+/-}{ }^{*} P<0 \cdot 05$.

in body weight, which was somewhat similar to that seen in GTG-injected WT mice. Our results also showed no significant difference in abdominal fat weight between obese IRS $-1^{+/-}$and obese WT mice (data not shown). These findings suggest that heterozygous disruption of the IRS-1 gene does not have a major impact on hypothalamic lesion-induced hyperphagia and increased fat mass. Not only obese IRS $-1^{+/}$mice but also obese WT mice showed impaired response to blood glucose upon insulin challenge, demonstrating that insulin resistance is accompanied by hypothalamic obesity in these mice. Interestingly, although IRS-1 ${ }^{+/-}$and WT mice acquire a similar increase of body weight, obese IRS $-1^{+/-}$mice showed more profound insulin resistance than obese WT mice during the insulin tolerance test.

Despite the profound insulin resistance in obese IRS$1^{+/-}$mice, there was no difference in fasting blood glucose levels between obese IRS-1 $1^{+/-}$and obese WT mice. This may be due to compensatory changes manifested by increased insulin secretion by increased numbers of pancreatic $\beta$-cells in obese IRS-1 $1^{+/}$mice. It is also of note that there was no significant difference in fasting blood glucose, fasting insulin levels, and islet size between lean IRS-1 $1^{+/-}$and lean WT mice. These results indicate that the impact of heterozygous knockout of the IRS-1 gene on glucose homeostasis and insulin sensitivity becomes overt only after induction of obesity. Indeed, the additive effect of heterozygous disruption of the IRS-1 gene on insulin resistance and pathogenesis of diabetes is supported by the results that double-heterozygous knockout of the IRS-1 gene and insulin receptor gene in the mice is more diabetogenic than single hetero-knockout of each gene (Kido et al. 2000). In the present study, we observed upregulation of IRS-2 protein in both the liver and muscles in lean IRS-1 ${ }^{+/-}$mice. This could in part explain the normal glucose tolerance and insulin sensitivity in lean IRS-1 ${ }^{+/-}$mice.

Abnormalities of early steps of insulin signaling pathway are known to cause insulin resistance in vivo and in vitro. In animal models of insulin resistance as well as in diabetic subjects, decreased binding of insulin to the insulin receptor, decreased receptor kinase activity, and decreased expression levels of insulin receptor and IRS-1 and IRS-2 have been demonstrated in the liver and skeletal muscles (Kahn et al. 1973, Soli et al. 1975, Folli et al. 1993). To determine the mechanism that underlies the profound

Figure 5 Morphological analysis of the pancreas obtained from 50-week-old mice. Hematoxylin-eosin (HE) stained (A-D) sections of the pancreas obtained from representative lean WT (A), lean IRS- $1^{+1-}$ (B), obese WT (C) and obese IRS- $1^{+1-}$ (D) mice. The samples were fixed, sectioned and stained with HE. Photographs show the typical islets of each group (magnification $\times 40$ ). Immunohistochemical analysis of islets of obese WT and obese IRS $-1^{+/}$mice $(E-H)$. Pancreases were obtained from 50-week-old mice, and sections were immunostained with anti-insulin (E, F) or anti-glucagon and anti-somatostatin cocktail antibodies $(\mathrm{G}, \mathrm{H})$. Photographs show the typical islets of each group (magnification $\times 100$ ). 

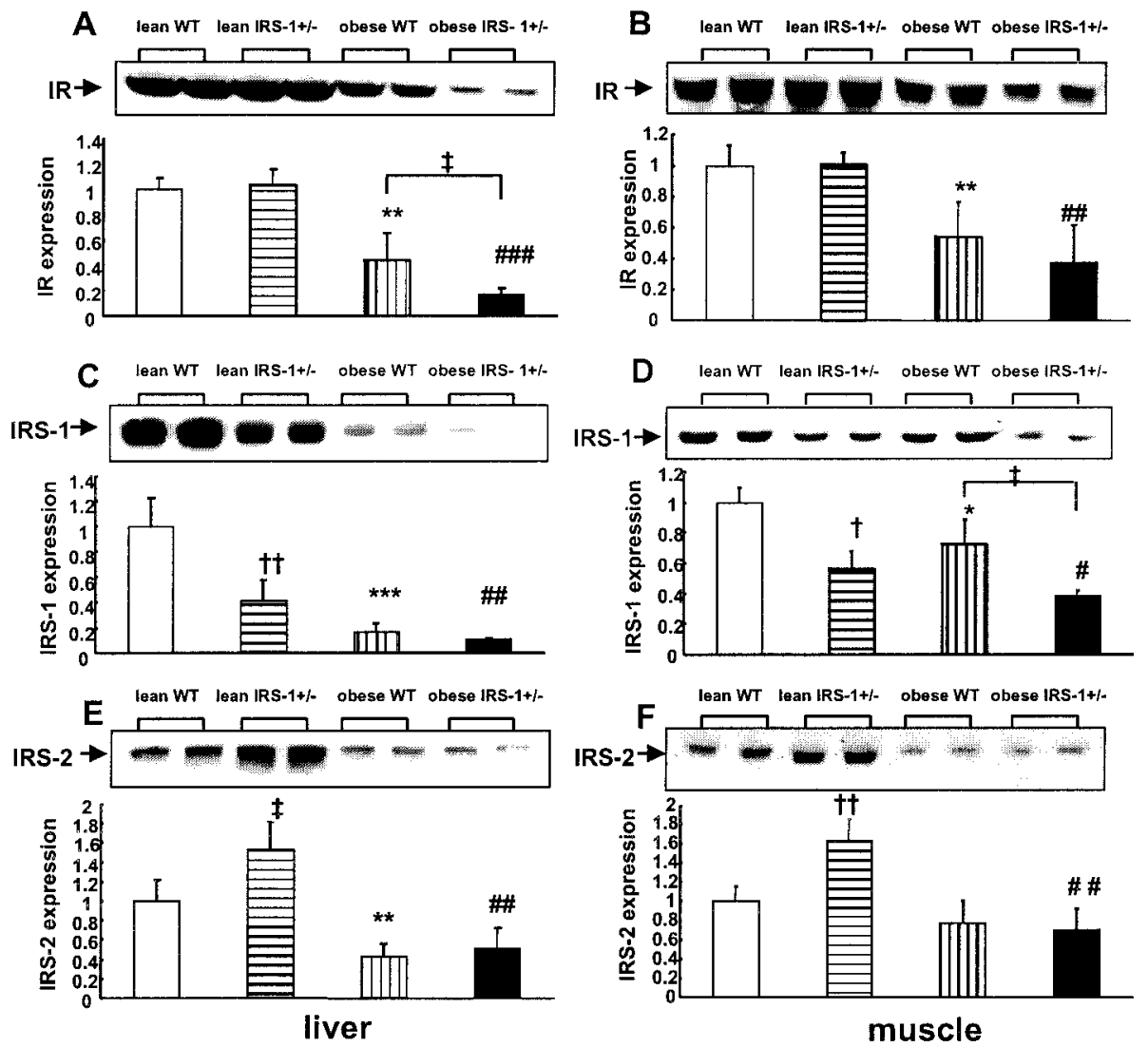

Figure 7 Expression levels of insulin receptor and IRS-1 and IRS-2 in the liver and muscles. Equal amounts of protein obtained from the liver (left panels) and muscles (right panels) were separated by SDS-PAGE in duplicate and immunoblotted with anti-insulin receptor (IR) (A, B), anti-IRS-1 (C, D) or anti-IRS-2 (E, F) antibody. Representative results of Western blot analysis are shown above each bar plot, and quantitative analysis of the signals by NIH image analysis software is shown below the blots. The expression levels are relative to those of lean WT and expressed as means \pm S.D. of five independent experiments (total ten animals). ${ }^{*} P<0 \cdot 05,{ }^{* *} P<0 \cdot 01,{ }^{*} * * P<0 \cdot 001$ vs lean WT, ${ }^{*} P<0 \cdot 05$, ${ }^{\# \#} P<0.01,{ }^{\# \# \#} P<0.001$ vs lean IRS $-1^{+1-},{ }^{\dagger} P<0 \cdot 05,{ }^{\dagger+} P<0.01$ vs lean WT, ${ }^{\ddagger} P<0.05$.

insulin resistance observed in obese IRS-1 $1^{+/-}$mice, we examined the expression of insulin receptor and IRS-1 and IRS-2 in the liver and striated muscles.

As shown in other obese animal models (Folli et al. 1993, Saad et al. 1993, Kerouz et al. 1997), the expression levels of insulin receptor and IRS-1 and IRS-2 in the liver and muscles of our obese mice groups were lower than in the respective lean controls. We found that, in addition to the decrease in IRS-1 expression, insulin receptor in the liver in obese IRS $-1^{+/-}$mice was significantly lower than in obese WT. It is also of note that IRS-2 expression in the liver and muscles was upregulated in lean IRS $-1^{+/-}$ mice, and this upregulation was blunted in obese IRS$1^{+/}$mice. Based on the results of knockout mice of either the IRS-1 or IRS-2 gene, several investigators proposed that IRS-1 is an important substrate for the metabolic actions of insulin in the muscles while IRS-2 is necessary for insulin action in the liver (Araki et al. 1994, Tamemoto et al. 1994, Withers et al. 1998). The importance of the insulin receptor in the muscles and liver has also been confirmed by muscle- and liver-specific disruption of the insulin receptor in mice (Brüning et al. 1998, Wojtaszewski et al. 1999, Michael et al. 2000). Therefore, the decrease in insulin receptor and IRS-1 in both tissues and blunted upregulation of IRS-2 protein could explain the profound insulin resistance in obese IRS-1 $1^{+/-}$mice.

We also studied the PI 3-kinase activity, a key signal involved in insulin-induced glucose uptake in peripheral tissues and regulation of glyconeogenesis in the liver (Agati et al. 1998). Our results showed that PI 3-kinase activity in the liver and muscles was significantly reduced in obese mice. This reduction could be explained by the low expression of insulin receptor and IRS-1 and IRS-2 in both tissues. We also found a significant reduction in 


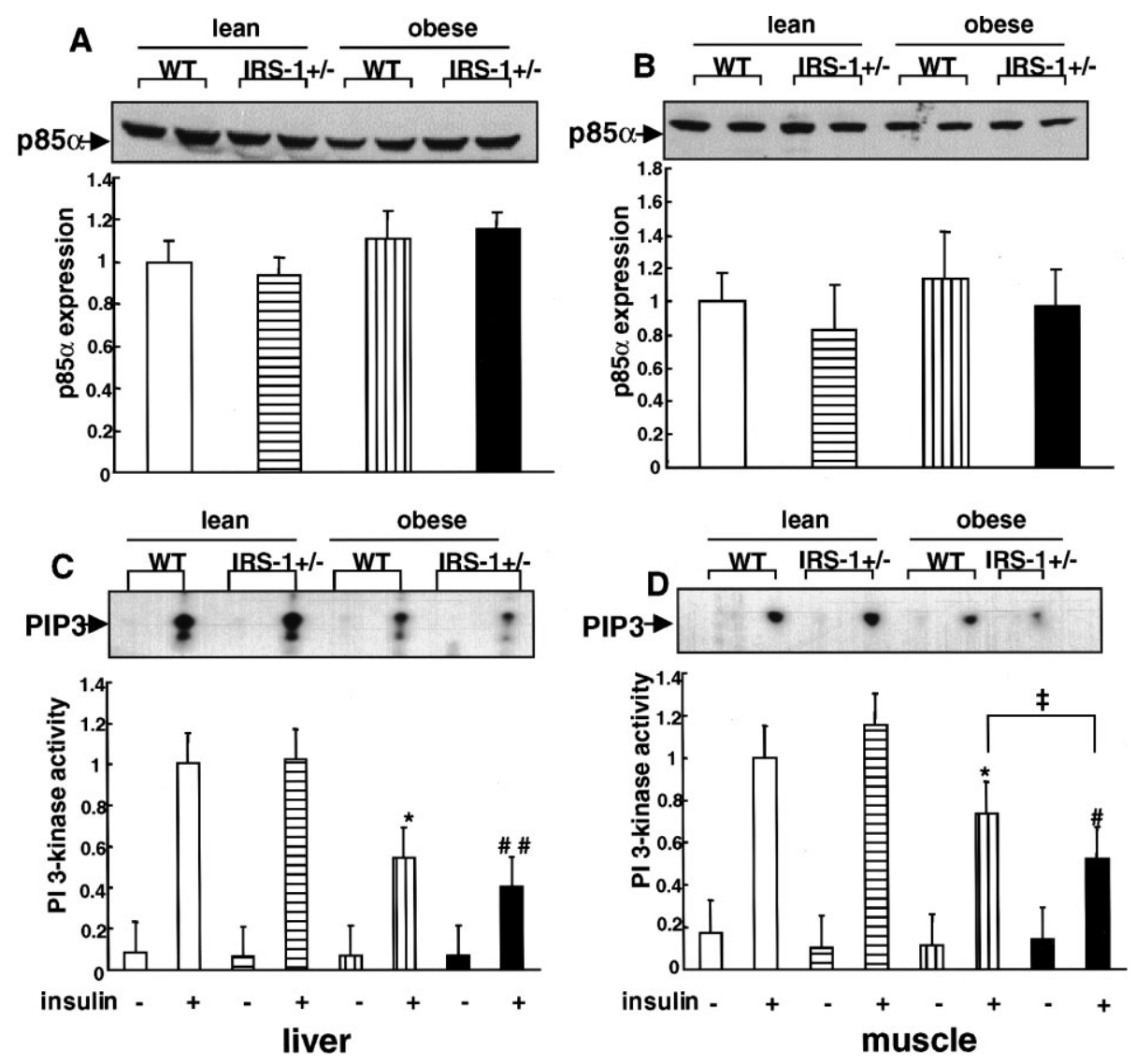

Figure 8 Expression of p85 $\alpha$ phosphatidylinositol (PI) 3-kinase and phosphotyrosine (PY)-associated PI 3-kinase activities in the liver and muscles. Equal amounts of protein obtained from the liver (A) and muscles (B) were separated by SDS-PAGE in duplicate and immunoblotted with anti-p85 $\alpha$ antibody. Animals were injected with $5 \mathrm{U}$ of regular human insulin or saline in the portal vein. Liver and muscles were removed 1 and 3 min later. Equal amounts of protein were subjected to immunoprecipitation with PY antibody followed by PI 3-kinase assays as described in Materials and Methods. ${ }^{3} \mathrm{P}$ incorporation into PI 3 phosphate (PIP3) in immunoprecipitates of the liver (C) and muscles (D) was quantified using NIH image analysis software. Expression levels are relative to those of lean WT mice under insulin stimulation and expressed as means \pm S.D. of five independent experiments (total ten animals). ${ }^{\star} P<0.05$ vs lean WT, ${ }^{\#} P<0 \cdot 05,{ }^{\# \#} P<0.01$ vs lean IRS- $1^{+1-},{ }^{\ddagger} P<0.05$.

insulin-stimulated PI 3-kinase activity in the muscles of obese IRS $-1^{+/-}$mice compared with obese WT mice. This could be, at least in part, due to reduced expression of IRS-1.

However, an important question remains unanswered: what are the mechanisms that regulate the expression of these molecules? It is known that chronic insulin treatment downregulates the expression and/or the phosphorylation of insulin signaling molecules, including insulin receptor and IRS-1 and IRS-2 (Friedman et al. 1997, Kerouz et al. 1997). In our model, the expression levels of insulin receptor and IRS-1 were low while serum insulin levels were high in obese IRS-1 ${ }^{+/-}$and obese WT. At present, it is not clear how insulin receptor is downregulated under a chronic hyperinsulinemic state. On the other hand, previous studies proposed that downregulation of IRS-1 protein in the presence of hyperinsulinemia is due to the degradation of IRS-1 protein (Araki et al. 1995). It is also reported that IRS-2 expression is negatively regulated by insulin by suppressing gene transcription and enhancing protein degradation (Rui et al. 2001, Zhang et al. 2001). Interestingly, IRS-2 protein, which is upregulated to supernormal levels in lean IRS-1 ${ }^{+/-}$mice, was reduced in obese IRS $-1^{+1-}$ mice, to levels as low as those seen in obese WT mice. It is possible that IRS-2 is upregulated in lean IRS $-1^{+/-}$by reduction of the insulin signal through IRS-1, and chronic hyperinsulinemia could cause a downregulation of IRS-2 protein in both obese mice. It is also reported that factors produced by adipocytes, such as adipocytokines and free fatty acids, can modulate the 
insulin signaling pathway (Hotamisligil et al. 1994, Dresner et al. 1999, Griffin et al. 1999). Further studies are therefore necessary to determine the precise mechanism(s) involved in the regulation of these proteins in our mouse models.

Although insulin resistance in obese IRS-1 ${ }^{+/-}$mice was more severe than in obese WT mice, there was no significant difference in fasting glucose levels between these two groups of mice. This is probably due to the compensation by increased insulin secretion from hypertrophied pancreatic islets. The latter were larger in both groups of obese mice compared with their lean controls. Furthermore, the mean islet size of obese IRS $-1^{+/-}$mice was significantly larger than that of obese WT mice, and this enlargement was, at least in part, due to an increased number of pancreatic $\beta$-cells. It is known that vagal hyperactivity induced by ventromedial hypothalamic lesions stimulates proliferation of pancreatic $\beta$-cells through a cholinergic receptor mechanism (Kiba et al. 1996). On the other hand, as shown in Fig. 6, the increase in islet size (which was larger than that of the $\beta$-cell number per islet) suggested possible $\beta$-cell hypertrophy in obese IRS $-1^{+/-}$mice. We examined the size of $\beta$-cells in some islets by microscopy, and found that obese IRS $-1^{+/-}$ mice tended to have larger $\beta$-cells compared with obese WT mice, albeit statistically insignificant (data not shown). Thus, we could not exclude a possibility of $\beta$-cell hypertrophy in obese IRS $-1^{+/-}$mice. Considered together, the enlargement of each islet might be the result of both an increased number of $\beta$-cells and $\beta$-cell hypertrophy. It is known that other obese models such as ob/ob mice (Tomita et al. 1992) and lean insulin-resistant models such as IRS-1 ${ }^{-1-}$ mice (Brüning et al. 1997) also show an increase in islet mass. In our study, the size of islets paralleled the degree of insulin resistance in each mouse group. The regulation of pancreatic $\beta$-cell growth is not fully understood at present. It has been reported that the IGF-I signal mediated by IRS-2 is important for pancreatic $\beta$-cell growth (Schuppin et al. 1998), and recent studies proposed the involvement of Akt, a serine/threonine kinase activated by insulin or IGF-I stimulation, in $\beta$ cell growth (Tuttle et al. 2001). Further studies are necessary to investigate the insulin signaling pathway including Akt activity in $\beta$-cells in our model.

In conclusion, we have demonstrated in the present study that GTG administration induced obesity and insulin resistance in both IRS $-1^{+/-}$and WT mice. Importantly, obese IRS $-1^{+/-}$mice were more insulin-resistant and had larger islets than obese WT mice, although insulin sensitivity of lean IRS-1 ${ }^{+/-}$mice was similar to that of lean WT mice. Our results suggest that IRS- 1 gene polymorphisms might be associated with worsening of insulin sensitivity in humans in the presence of additional factor(s), such as obesity. These findings widen the scope of our understanding of the mechanism involved in the development of type 2 diabetes mellitus in obese subjects.

\section{Acknowledgements}

This work was supported in part by a grant for scientific research from the Ministry of Education, Science and Culture of Japan (No. 10671079, 12671117).

\section{References}

Agati JM, Yeagley D \& Quinn PG 1998 Assessment of the roles of mitogen-activated protein kinase, phosphatidylinositol 3-kinase, protein kinase $\mathrm{B}$, and protein kinase $\mathrm{C}$ in insulin inhibition of cAMP-induced phosphoenolpyruvate carboxykinase gene transcription. Journal of Biological Chemistry 273 18751-18759.

Almind K, Bjorbaek C, Vestergaard H, Hansen T, Echwald S \& Pedersen O 1993 Amino acid polymorphisms of insulin receptor substrate-1 in non-insulin dependent diabetes mellitus. Lancet 342 828-832.

Almind K, Inoue G, Pedersen O \& Kahn CR 1996 A common amino acid polymorphism in insulin receptor substrate- 1 causes impaired insulin signaling. Evidence from transfection studies. Journal of Clinical Investigation 97 2569-2575.

Araki E, Sun XJ, Haag BL III, Chuang LM, Zhang Y, Yang-Feng TL, White MF \& Kahn CR 1993 Human skeletal muscle insulin receptor substrate-1. Characterization of the cDNA, gene, and chromosomal localization. Diabetes 42 1041-1054.

Araki E, Lipes MA, Patti ME, Bruning JC, Haag B III, Johnson RS \& Kahn CR 1994 Alternative pathway of insulin signalling in mice with targeted disruption of the IRS-1 gene. Nature 372 186-190.

Araki E, Haag BL III, Matsuda K, Shichiri M \& Kahn CR 1995 Characterization and regulation of the mouse insulin receptor substrate gene promoter. Molecular Endocrinology 9 1367-1379.

Argetsinger LS, Hsu GW, Myers MG Jr, Billestrup N, White MF \& Carter-Su C 1995 Growth hormone, interferon-gamma, and leukemia inhibitory factor promoted tyrosyl phosphorylation of insulin receptor substrate-1. Journal of Biological Chemistry 270 14685-14692.

Brüning JC, Winnay J, Bonner-Weir S, Taylor SI, Accili D \& Kahn CR 1997 Development of a novel polygenic model of NIDDM in mice heterozygous for IR and IRS-1 null alleles. Cell 88 561-572.

Brüning JC, Michael MD, Winnay JN, Hayashi T, Horsch D, Accili D, Goodyear LJ \& Kahn CR 1998 A muscle-specific insulin receptor knockout exhibits features of the metabolic syndrome of NIDDM without altering glucose tolerance. Molecular Cell 2 $559-569$.

Clausen JO, Hansen T, Bjorbaek C, Echwald SM, Urhammer SA, Rasmussen S, Andersen CB, Hansen L, Almind K, Winther K, Haraldsdottir J, Johnsen KB \& Pedersen O 1995 Insulin resistance: interactions between obesity and a common variant of insulin receptor substrate-1. Lancet 346 397-402.

Dresner A, Laurent D, Marcucci M, Griffin ME, Dufour S, Cline GW, Slezak LA, Andersen DK, Hundal RS, Rothman DL, Petersen KF \& Shulman GI 1999 Effects of free fatty acids on glucose transport and IRS-1-associated phosphatidylinositol 3-kinase activity. Journal of Clinical Investigation 103 253-259.

Folli F, Saad MJ, Backer JM \& Kahn CR 1993 Regulation of phosphatidylinositol 3-kinase activity in liver and muscle of animal models of insulin-resistant and insulin-deficient diabetes mellitus. Journal of Clinical Investigation 92 1787-1794.

Friedman JE, Ishizuka T, Liu S, Farrell CJ, Bedol D, Koletsky RJ, Kaung HL \& Ernsberger P 1997 Reduced insulin receptor signaling in the obese spontaneously hypertensive Koletsky rat. American Journal of Physiology 273 E1014-E1023.

Griffin ME, Marcucci MJ, Cline GW, Bell K, Barucci N, Lee D, Goodyear LJ, Kraegen EW, White MF \& Shulman GI 1999 Free fatty acid-induced insulin resistance is associated with activation of 
protein kinase $\mathrm{C}$ theta and alterations in the insulin signaling cascade. Diabetes 48 1270-1274.

Hager J, Zouali H, Velho G \& Froguel P 1993 Insulin receptor substrate (IRS-1) gene polymorphisms in French NIDDM families. Lancet 3421430.

Hara K, Yonezawa K, Sakaue H, Ando A, Kotani K, Kitamura T, Kitamura Y, Ueda H, Stephens L, Jackson TR, Hawkins PT, Dhand R, Clark AD, Holman GD, Waterfield MD \& Kasuga M 1994 1-Phosphatidylinositol 3-kinase activity is required for insulin-stimulated glucose transport but not for RAS activation in CHO cells. PNAS 91 7415-7419.

Heilbronn LK, Kind KL, Pancewicz E, Morris AM, Noakes M \& Clifton PM 2000 Association of -3826 G variant in uncoupling protein-1 with increased BMI in overweight Australian women. Diabetologia 43 242-244.

Hotamisligil GS, Murray DL, Choy LN \& Spiegelman BM 1994 Tumor necrosis factor alpha inhibits signaling from the insulin receptor. PNAS 91 4854-4858.

Kahn CR, Neville DM Jr \& Roth J 1973 Insulin-receptor interaction in the obese-hyperglycemic mouse. A model of insulin resistance. Journal of Biological Chemistry 248 244-250.

Kerouz NJ, Horsch D, Pons S \& Kahn CR 1997 Differential regulation of insulin receptor substrates-1 and -2 (IRS-1 and IRS-2) and phosphatidylinositol 3-kinase isoforms in liver and muscle of the obese diabetic $(\mathrm{ob} / \mathrm{ob})$ mouse. Journal of Clinical Investigation 100 3164-3172.

Kiba T, Tanaka K, Numata K, Hoshino M, Misugi K \& Inoue S 1996 Ventromedial hypothalamic lesion-induced vagal hyperactivity stimulates rat pancreatic cell proliferation. Gastroenterology 110 885-893.

Kido Y, Burks DJ, Withers D, Brüning JC, Kahn CR, White MF \& Accili D 2000 Tissue-specific insulin resistance in mice with mutations in the insulin receptor, IRS-1, and IRS-2. Journal of Clinical Investigation 105 199-205.

King H \& Rewers M 1993 Global estimates for prevalence of diabetes mellitus and impaired glucose tolerance in adults. WHO Ad Hoc Diabetes Reporting Group. Diabetes Care 16 157-177.

Le Marchand Y, Freychet P \& Jeanrenaud B 1978 Longitudinal study on the establishment of insulin resistance in hypothalamic obese mice. Endocrinology 102 74-85.

Ludwig DS, Vidal-Puig A, O'Brien RM, Printz RL, Granner DK, Moller DE \& Flier JS 1996 Examination of the phosphoenolpyruvate carboxykinase gene promoter in patients with noninsulin-dependent diabetes mellitus. Journal of Clinical Endocrinology and Metabolism $\mathbf{8 1}$ 503-506.

Michael MD, Kulkarni RN, Postic C, Previs SF, Shulman GI, Magnuson MA \& Kahn CR 2000 Loss of insulin signaling in hepatocytes leads to severe insulin resistance and progressive hepatic dysfunction. Molecular Cell 6 87-97.

Myers MG Jr, Grammer TC, Wang LM, Sun XJ, Pierce JH, Blenis J \& White MF 1994 Insulin receptor substrate-1 mediates phosphatidylinositol $3^{\prime}$-kinase and p70S6k signaling during insulin, insulin-like growth factor-1, and interleukin-4 stimulation. Journal of Biological Chemistry $26928783-28789$.

O'Rahilly S, Gray H, Humphreys PJ, Krook A, Polonsky KS, White A, Gibson S, Taylor K \& Carr C 1995 Brief report: impaired processing of prohormones associated with abnormalities of glucose homeostasis and adrenal function. New England Journal of Medicine 333 1386-1390.

Ristow M, Muller-Wieland D, Pfeiffer A, Krone W \& Kahn CR 1998 Obesity associated with a mutation in a genetic regulator of adipocyte differentiation. New England Journal of Medicine 339 953-959.

Ristow M, Vorgerd M, Mohlig M, Schatz H \& Pfeiffer A 1999 Insulin resistance and impaired insulin secretion due to phosphofructo-1-kinase-deficiency in humans. Journal of Molecular Medicine 77 96-103.

Rui L, Fisher TL, Thomas J \& White MF 2001 Regulation of insulin/insulin-like growth factor-1 signaling by proteasomemediated degradation of insulin receptor substrate-2. Journal of Biological Chemistry 276 40362-40367.

Saad MJ, Folli F, Kahn JA \& Kahn CR 1993 Modulation of insulin receptor, insulin receptor substrate-1, and phosphatidylinositol 3-kinase in liver and muscle of dexamethasone-treated rats. Journal of Clinical Investigation 92 2065-2072.

Schuppin GT, Pons S, Hugl S, Aiello LP, King GL, White M \& Rhodes CJ 1998 A specific increased expression of insulin receptor substrate 2 in pancreatic beta-cell lines is involved in mediating serum-stimulated beta-cell growth. Diabetes 47 1074-1085.

Soli AH, Kahn CR, Neville DM Jr \& Roth J 1975 Insulin receptor deficiency in genetic and acquired obesity. Journal of Clinical Investigation $\mathbf{5 6}$ 769-780.

Sun XJ, Rothenberg P, Kahn CR, Backer JM, Araki E, Wilden PA, Cahill DA, Goldstein BJ \& White MF 1991 Structure of the insulin receptor substrate IRS-1 defines a unique signal transduction protein. Nature 352 73-77.

Tamemoto H, Kadowaki T, Tobe K, Yagi T, Sakura H, Hayakawa T, Terauchi Y, Ueki K, Kaburagi Y, Satoh S, Sekihara H, Yoshioka S, Horikoshi H, Furuta Y, Ikawa Y, Kasuga M, Yazaki Y \& Aizawa S 1994 Insulin resistance and growth retardation in mice lacking insulin receptor substrate-1. Nature 372 182-186.

Tomita T, Doull V, Pollock HG \& Krizsan D 1992 Pancreatic islets of obese hyperglycemic mice (ob/ob). Pancreas 7 367-375.

Tsao TS, Katz EB, Pommer D \& Charron MJ 2000 Amelioration of insulin resistance but not hyperinsulinemia in obese mice overexpressing GLUT4 selectively in skeletal muscle. Metabolism 49 340-346.

Tuttle RL, Gill NS, Pugh W, Lee JP, Koeberlein B, Furth EE, Polonsky KS, Naji A \& Birnbaum MJ 2001 Regulation of pancreatic beta-cell growth and survival by the serine/threonine protein kinase Akt1/PKBalpha. Nature Medicine 7 1133-1137.

Ura S, Araki E, Kishikawa H, Shirotani T, Todaka M, Isami S, Shimoda S, Yoshimura R, Matsuda K, Motoyoshi S, Miyamura N, Kahn CR \& Shichiri M 1996 Molecular scanning of the insulin receptor substrate-1 (IRS-1) gene in Japanese patients with NIDDM: identification of five novel polymorphisms. Diabetologia 39 600-608.

Withers DJ, Gutierrez JS, Towery H, Burks DJ, Ren JM, Previs S, Zhang Y, Bernal D, Pons S, Shulman GI, Bonner-Weir S \& White MF 1998 Disruption of IRS-2 causes type 2 diabetes in mice. Nature 391 900-904.

Wojtaszewski JF, Higaki Y, Hirshman MF, Michael MD, Dufresne SD, Kahn CR \& Goodyear LJ 1999 Exercise modulates postreceptor insulin signaling and glucose transport in muscle-specific insulin receptor knockout mice. Journal of Clinical Investigation 104 1257-1264.

Yoshimura R, Araki E, Ura S, Todaka M, Tsuruzoe K, Furukawa N, Motoshima H, Yoshizato K, Kaneko K, Matsuda K, Kishikawa H \& Shichiri M 1997 Impact of natural IRS-1 mutations on insulin signals: mutations of IRS- 1 in the PTB domain and near SH2 protein binding sites result in impaired function at different steps of IRS-1 signaling. Diabetes 46 929-936.

Zhang J, Ou J, Bashmakov Y, Horton JD, Brown MS \& Goldstein JL 2001 Insulin inhibits transcription of IRS-2 gene in rat liver through an insulin response element (IRE) that resembles IREs of other insulin-repressed genes. PNAS 98 3756-3761.

Received 22 April 2002

Accepted 29 April 2002 